\title{
Foreseeing the future of the sports championships sector after the Covid-19 pandemic
}

\begin{abstract}
:
The shock of COVID 19 has surprised the world and affected all walks of life. The gradual return to matches required precautionary measures that affected the nature of sports life. Based on the foregoing, it can be said that post-COVID-19 forecasting will help in making accurate decisions in light of the available data.

The purpose of this study was to Foreseeing the future of the sports championships sector after the COVID19 pandemic. The sample for the research consisted of 210 respondents from all sectors belonging to the sports field and associated with the championship sector. The search questionnaire was applied for a period of 6 weeks. The questionnaire consists of 34 statements that include four axes. - The questionnaire was distributed via Google form with a link https://forms.gle/Zxos6xnyS1dduNsB7

Conclusions: - One to two years, the expected period for the return of the sports tournaments as they were. - The sportswear and personal equipment of the players will develop. -There will be developments in the structural engineering of playgrounds to achieve health safety. - Some terms of contracts between professional players, clubs, and sports bodies will change.
\end{abstract}

Keywords: championships sector. COVID19. Foreseeing

Introduction:

The shock of COVID 19 has surprised the world and affected all walks of life, including the sports field, which is an important and essential part of human life. The global pandemic has subjected the whole world to fundamental difficulties. The future of the championships field has suffered from a major setback that affected all its activities. Where matches, television broadcasts, advertisements, and monetary revenues have stopped.

The gradual return to matches required precautionary measures that affected the nature of sports life. This has necessitated social distancing by maintaining distances between athletes and a commitment to stay home. These measures aim to limit the spread of COVID 19 and achieve health safety. All these sudden changes affected the psychological side of all workers in the sports field. Their lives have changed as the traditional form of training and playing matches, the surrounding (lost) crowd on the field, and the paid services of many individuals have become elusive hopes. All of this has been replaced by obligations limiting personal freedom that has been the basis of the athlete's life around the world.

We believe that a Covid-19 pandemic is a unique event, and it is the largest and most prominent during the years following the Second World War, where multiple problems afflicted the economies of the sports field. These economies in which hundreds of billions of dollars move the value of the global sports industry to various economic entities, ranging from gigantic deals in tickets, hospitality, media, and sponsorship, to the small deals in a few dollars that people earn selling food or souvenirs in front of the stadiums.

Health insurance has imposed on athletes a package of measures aimed at preventing infection, such as greatly reducing the number of athletes in matches, medical examination for COVID 19 for thousands of athletes before they are allowed to 
enter competitions, attention to preventive sports medicine, and international scientific cooperation seeking a health protocol that guarantees the safe return of the sport.

Therefore, we seek to see the horizon of the effects of this pandemic, on collective and individual sports activities and all related tools, equipment, clothes, stadiums, and calendars, especially international ones, such as the summer Olympic Games expected in Tokyo and postponed to 2021 and so on. By polling the opinions of a group of experts and specialists on the challenges and developments that the next few years will bring, while reducing the level of uncertainty, and then placing the results of this research in front of the policymaker with the aim of planning's future after one of the biggest global events in the modern era. Based on the foregoing, it can be said that postCOVID-19 forecasting will help in making accurate and good decisions at the lowest cost in light of the available data.

\section{Purpose:}

Foreseeing the future of the sports championships sector after the Covid-19 pandemic in the medium term.

\section{Terms:}

- Covid-19 disease (WHO definition): It is an infectious disease caused by the last virus that was discovered from a strain of Coronaviruses. Covid-19 has now turned into a pandemic affecting many countries of the world, (3).

- The sports championships sector (procedural definition) : the sector that prepares athletes to participate in national, international, or global sports competitions.

\section{- Materials and Methods:}

The search questionnaire was applied on an Arab and international scale for a period of 6 weeks from May 28 to July 8, 2020.

- The sample for the research consisted of 210 respondents (attached 1) from all sectors belonging to the sports field and associated with the championship sector, who work at levels ranging from national to international or Olympic in one or more of the following fields:

Sports Training - Sports Administration (Civil / Military) - Sports Tournaments Ph.D. Academics - Sports Media - Sports Marketing - Sports Medicine.

-The sample included respondents from 23 countries around the world:

Japan - The United States of America - Germany - Italy - Portugal - Costa Rica Tanzania - Iran - England - Egypt - Libya - Algeria - Tunisia - Morocco - Jordan Palestine - Lebanon - Iraq - Saudi Arabia - Bahrain - Oman - Kuwait - Syria.

- A questionnaire to Foreseeing the future of the sports championships sector after the Covid-19 pandemic.

In preparing the questionnaire, the researchers relied on:

Reviewing the foresight science literature as an attempt to discover problems before they occur, and then preparing early to confront new future variables. In this regard, Denis Loveridge (2009) indicates that studies Foresight place broad hopes on human horizons that are more broadly available from the tools and knowledge that we have (2: 333).

- The questionnaire consists of 34 statements that include four axes:

1- General Sports Axis 2 - Psychological axis

3 -Economic axis. $\quad 4$ - The health axis

-The assessment is based on five options of the "Likart" grading scales:

A- Strongly Disagree B- Disagree C- Neutral D-Agree E-Strongly Agree 
-The questionnaire was available in Arabic and English.

- Distribute the questionnaire through the Google Form by sending the electronic link https://forms.gle/Zxos6xnyS1dduNsB7 to an email or Whats App.

\section{-Validity and reliability:}

The validity of internal consistency was used by using the correlation coefficient between the degree of each statement and the degree of the axis in the questionnaire, as well as between the axis score and the total score of the questionnaire on An exploratory sample of (52) respondents.

Table (1) the correlation ( $r$ ) between the sentence score and the axis score in the questionnaire $(\mathbf{N}=\mathbf{5 2})$

\begin{tabular}{|c|c|c|c|c|c|}
\hline sentence & correlation & sentence & correlation & sentence & correlation \\
\hline \multicolumn{2}{|c|}{ General Sports Axis } & 13 & $* * 0.632$ & 24 & $* * 0.656$ \\
\hline 1 & $* 0.329$ & 14 & $* * 0.486$ & 25 & $* * 0.554$ \\
\hline 2 & $* * 0.515$ & 15 & $* * 0.454$ & 26 & $* * 0.365$ \\
\hline 3 & $* * 0.485$ & \multicolumn{2}{|c|}{ Psychological axis } & \multicolumn{2}{|c|}{ The health axis } \\
\hline 4 & $* 0.298$ & 16 & $* * 0.824$ & 27 & $* * 0.571$ \\
\hline 5 & $* 0.275$ & 17 & $* * 0.746$ & 28 & $* * 0.762$ \\
\hline 6 & $* 0.288$ & 18 & $* * 0.934$ & 29 & $* * 0.708$ \\
\hline 7 & $* * 0.459$ & 19 & $* * 0.926$ & 30 & $* * 0.599$ \\
\hline 8 & $* * 0.458$ & \multicolumn{2}{|c|}{ Economic axis } & 31 & $* * 0.669$ \\
\hline 9 & $* * 0.517$ & 20 & $* * 0.684$ & 32 & $* * 0.703$ \\
\hline 10 & $* * 0.564$ & 21 & $* * 0.456$ & 33 & $* * 0.555$ \\
\hline 11 & $* * 0.590$ & 22 & $* * 0.753$ & 34 & $* 0.296$ \\
\hline 12 & $* * 0.649$ & 23 & $* * 0.720$ & & \\
\hline
\end{tabular}

Table (2) the correlation between the axis score and the total score of the questionnaire $(\mathbf{N}=52)$

\begin{tabular}{|c||c||c|}
\hline \hline $\mathrm{N}$ & axis score & correlation \\
\hline \hline 1 & General Sports Axis & $0.790 * *$ \\
\hline 2 & Psychological axis & $0.750^{* *}$ \\
\cline { 2 - 3 } 3 & Economic axis & $0.782^{* *}$ \\
\cline { 2 - 3 } 4 & Health axis & $0.619 * *$ \\
\hline \hline
\end{tabular}

*The tabular correlation coefficient " $r$ " was significant at the level of $0.05=0.273$, $* *$ at the level of $0.01=0.354$

It is evident from Tables (1 and 2) that all correlation coefficients have significant values at the level of (0.01), which indicates the internal consistency of the list 
expressions.

Reliability:

To determine the reliability coefficient, the researcher used the method of re-applying the questionnaire to an exploratory sample with 22 individuals, Table No. (3).

Table (3) the first and second measures of the questionnaire and the reliability coefficient

\begin{tabular}{|r|c|c|c|c|c|c|c|}
\hline \hline \multicolumn{3}{|c|}{ first measurement } & \multicolumn{3}{c|}{ second measurement } & $\begin{array}{c}\text { difference } \\
\text { between } \\
\text { the two } \\
\text { averages }\end{array}$ & $\begin{array}{c}\text { Reliability } \\
\mathrm{r}\end{array}$ \\
\hline $\mathrm{X} 1$ & $\mathrm{SD} 1$ & $\mathrm{SC} 1$ & $\mathrm{X} 2$ & $\mathrm{SD} 2$ & $\mathrm{SC} 2$ & $\mathrm{~N}=22$ & $* * 0.89$ \\
\hline \hline 123.55 & 8.36 & $0.46-$ & 124.41 & 8.12 & $0.80-$ & 0.86 & $* 622$ \\
\hline \hline
\end{tabular}

The tabular $\mathrm{t}$ is at the level of $0.01=0.537 * *$ Significant at the level of 0.01

It is evident from Table (3) that the reliability coefficient (0.89), which confirms that the questionnaire is reliable.

Results:

The researchers adopted the result of the statements that were accepted or rejected by $(60 \%)$ or more. 
Table (4) chi square test for general sport axis phrases $(n=210)$

\begin{tabular}{|c|c|c|c|c|c|c|c|c|c|c|c|c|c|c|}
\hline \multirow{2}{*}{$\begin{array}{l}\text { chi } \\
\text { square }\end{array}$} & \multirow{2}{*}{$\begin{array}{l}\text { Total } \\
\text { approv } \\
\text { al } \\
\text { percent } \\
\text { age }\end{array}$} & \multirow{2}{*}{$\begin{array}{l}\text { Total } \\
\text { percent } \\
\text { age of } \\
\text { disappr } \\
\text { oval }\end{array}$} & \multicolumn{2}{|c|}{$\begin{array}{c}\text { Strongly } \\
\text { Agree }\end{array}$} & \multicolumn{2}{|c|}{ Agree } & \multicolumn{2}{|c|}{ Neutral } & \multicolumn{2}{|c|}{ Disagree } & \multicolumn{2}{|c|}{$\begin{array}{l}\text { Strongly } \\
\text { Disagree }\end{array}$} & \multirow[b]{2}{*}{ Phrases } & \multirow[b]{2}{*}{$\mathbf{N}$} \\
\hline & & & $\%$ & كs & $\%$ & ك & $\%$ & ك & $\%$ & ك & $\%$ & ك & & \\
\hline${ }^{* * 68.6}$ & 25.2 & 56.7 & 1.9 & 4.0 & 23.3 & 49.0 & 18.1 & 38.0 & 37.6 & 79.0 & 19.0 & 40.0 & $\begin{array}{l}\text { Because of COVID 19, Virtual sports will } \\
\text { spread to partially replace physical } \\
\text { sports }\end{array}$ & 1 \\
\hline **213.8 & 83.3 & 10.0 & 26.7 & 56.0 & 56.7 & 119.0 & 6.7 & 14.0 & 8.1 & 17.0 & 1.9 & 4.0 & $\begin{array}{l}\text { The level of sports performance for team } \\
\text { games (such as basketball) will be } \\
\text { negatively affected due to COVID } 19\end{array}$ & 2 \\
\hline ** 123.4 & 67.6 & 24.8 & 19.0 & 40.0 & 48.6 & 102.0 & 7.6 & 16.0 & 19.0 & 40.0 & 5.7 & 12.0 & $\begin{array}{l}\text { The progress rate of individual games } \\
\text { (swimming - athletics - weightlifting-...) } \\
\text { will be negatively affected due to COVID } 19\end{array}$ & 3 \\
\hline${ }^{\star *} 90.7$ & 48.1 & 29.5 & 8.1 & 17.0 & 40.0 & 84.0 & 22.4 & 47.0 & 26.2 & 55.0 & 3.3 & 7.0 & Athletes will quickly adapt to COVID19 & 4 \\
\hline$\star \star 85.0$ & 26.7 & 64.8 & 10.0 & 21.0 & 16.7 & 35.0 & 8.6 & 18.0 & 43.8 & 92.0 & 21.0 & 44.0 & $\begin{array}{l}\text { Does COVID } 19 \text { have any positive } \\
\text { effects on the championship sector? }\end{array}$ & 5 \\
\hline **118.5 & 52.9 & 18.6 & 8.1 & 17.0 & 44.8 & 94.0 & 28.6 & 60.0 & 15.2 & 32.0 & 3.3 & 7.0 & $\begin{array}{l}\text { The Tokyo Olympic Games will be held } \\
\text { as scheduled in } 2021\end{array}$ & 6 \\
\hline$\star \star 75.6$ & 26.2 & 52.9 & 3.8 & 8.0 & 22.4 & 47.0 & 21.0 & 44.0 & 40.0 & 84.0 & 12.9 & 27.0 & $\begin{array}{l}\text { The Tokyo Olympic Games in } 2021 \\
\text { can be held without fans }\end{array}$ & 7 \\
\hline ** 260.3 & $\begin{array}{l}\text { After } 4 \\
\text { or } 5 \\
\text { years }\end{array}$ & $\begin{array}{l}\text { After } 1 \\
\text { or } 2 \\
\text { years }\end{array}$ & \multicolumn{2}{|c|}{ after 5 years } & \multicolumn{2}{|c|}{ after 4 years } & \multicolumn{2}{|c|}{ after 3 years } & \multicolumn{2}{|c|}{ after 2 years } & \multicolumn{2}{|c|}{ After 1 year } & \multirow[t]{2}{*}{$\begin{array}{l}\text { Sports tournaments will return to normal } \\
\text { after COVID } 19\end{array}$} & \multirow[t]{2}{*}{8} \\
\hline & 0.5 & 92.8 & 0 & 0 & 0.5 & 1 & 6.7 & 14 & 38.5 & 81 & 54.3 & 114 & & \\
\hline
\end{tabular}




\begin{tabular}{|c|c|c|c|c|c|c|c|c|c|c|c|c|c|c|}
\hline **116.2 & 50.0 & 24.8 & 4.3 & 9.0 & 45.7 & 96.0 & 25.2 & 53.0 & 17.6 & 37.0 & 7.1 & 15.0 & $\begin{array}{l}\text { COVID } 19 \text { will lead to the development of } \\
\text { sports equipment: balls/rackets/ nets / ... }\end{array}$ & 9 \\
\hline **251.8 & 74.3 & 12.9 & 11.0 & 23.0 & 63.3 & 133.0 & 12.9 & 27.0 & 9.5 & 20.0 & 3.3 & 7.0 & $\begin{array}{l}\text { COVID } 19 \text { will lead to the development of } \\
\text { sportswear and personal tools }\end{array}$ & 10 \\
\hline **261.6 & 79.5 & 9.5 & 15.7 & 33.0 & 63.8 & 134.0 & 11.0 & 23.0 & 6.7 & 14.0 & 2.9 & 6.0 & $\begin{array}{l}\text { COVID } 19 \text { will lead to the development of } \\
\text { structural engineering for open and } \\
\text { closed stadiums }\end{array}$ & 11 \\
\hline **110.8 & 60.0 & 21.9 & 13.8 & 29.0 & 46.2 & 97.0 & 18.1 & 38.0 & 20.0 & 42.0 & 1.9 & 4.0 & $\begin{array}{l}\text { Multinational sports teams will be } \\
\text { negatively affected (for example, the } \\
\text { Watford soccer team in England with } 20 \\
\text { nationalities) due to COVID } 19\end{array}$ & 12 \\
\hline **206.3 & 79.5 & 7.6 & 22.4 & 47.0 & 57.1 & 120.0 & 12.9 & 27.0 & 5.2 & 11.0 & 2.4 & 5.0 & $\begin{array}{l}\text { Due to COVID 19, scientific programs in } \\
\text { academic sports institutes should be } \\
\text { modified }\end{array}$ & 13 \\
\hline **202.0 & 80.0 & 11.4 & 23.3 & 49.0 & 56.7 & 119.0 & 8.6 & 18.0 & 9.5 & 20.0 & 1.9 & 4.0 & $\begin{array}{l}\text { The biggest obstacle to the return of } \\
\text { major sports tournaments, such as the } \\
\text { Olympics, is the participation of a very } \\
\text { large number of athletes from multiple } \\
\text { countries }\end{array}$ & 14 \\
\hline **244.3 & 90.0 & 4.3 & 34.3 & 72.0 & 55.7 & 117.0 & 5.7 & 12.0 & 3.8 & 8.0 & 0.5 & 1.0 & $\begin{array}{l}\text { Fear of COVID } 19 \text { will increase the role } \\
\text { of IT to protect athletes from injury }\end{array}$ & 15 \\
\hline
\end{tabular}


Table (5) chi square test for Psychological axis phrases $(n=210)$

\begin{tabular}{|c|c|c|c|c|c|c|c|c|c|c|c|c|c|c|}
\hline \multirow{2}{*}{$\begin{array}{l}\text { chi } \\
\text { square }\end{array}$} & \multirow{2}{*}{$\begin{array}{l}\text { Total } \\
\text { approv } \\
\text { al } \\
\text { percent } \\
\text { age }\end{array}$} & \multirow{2}{*}{$\begin{array}{c}\text { Total } \\
\text { percent } \\
\text { age of } \\
\text { disappr } \\
\text { oval }\end{array}$} & \multicolumn{2}{|c|}{$\begin{array}{c}\text { Strongly } \\
\text { Agree }\end{array}$} & \multicolumn{2}{|c|}{ Agree } & \multicolumn{2}{|c|}{ Neutral } & \multicolumn{2}{|c|}{ Disagree } & \multicolumn{2}{|c|}{$\begin{array}{l}\text { Strongly } \\
\text { Disagree }\end{array}$} & \multirow[b]{2}{*}{ Phrases } & \multirow[b]{2}{*}{$\mathbf{N}$} \\
\hline & & & $\%$ & ك5 & $\%$ & كs & $\%$ & ك & $\%$ & ك & $\%$ & s & & \\
\hline **325.5 & 89.5 & 4.8 & 21.9 & 46.0 & 67.6 & 142.0 & 5.7 & 12.0 & 3.8 & 8.0 & 1.0 & 2.0 & $\begin{array}{l}\text { Players' psychology will be negatively } \\
\text { affected by fear of infection with COVID } 19\end{array}$ & 16 \\
\hline **323.5 & 88.6 & 8.1 & 21.0 & 44.0 & 67.6 & 142.0 & 3.3 & 7.0 & 7.6 & 16.0 & 0.5 & 1.0 & $\begin{array}{l}\text { Anxiety and isolation will affect the } \\
\text { effectiveness of the training due to } \\
\text { COVID } 19\end{array}$ & 17 \\
\hline ** 137.1 & 60.0 & 30.5 & 11.4 & 24.0 & 48.6 & 102.0 & 9.5 & 20.0 & 26.7 & 56.0 & 3.8 & 8.0 & $\begin{array}{l}\text { The social distancing associated with } \\
\text { COVID } 19 \text { negatively affects relations } \\
\text { between players }\end{array}$ & 18 \\
\hline **133.1 & 55.2 & 33.3 & 8.6 & 18.0 & 46.7 & 98.0 & 11.4 & 24.0 & 29.5 & 62.0 & 3.8 & 8.0 & $\begin{array}{l}\text { The social distancing associated with } \\
\text { COVID } 19 \text { negatively affects relations } \\
\text { between players and coaches }\end{array}$ & 19 \\
\hline
\end{tabular}

chi square tabular at 0.01 level $=13.27 * *$ significant at 0.01 level 
Table (6) chi square test for Economic axis phrases $(n=210)$

\begin{tabular}{|c|c|c|c|c|c|c|c|c|c|c|c|c|c|c|}
\hline \multirow{2}{*}{$\begin{array}{c}\text { chi } \\
\text { square }\end{array}$} & \multirow{2}{*}{$\begin{array}{l}\text { Total } \\
\text { approv } \\
\text { al } \\
\text { percent } \\
\text { age }\end{array}$} & \multirow{2}{*}{$\begin{array}{l}\text { Total } \\
\text { percent } \\
\text { age of } \\
\text { disappr } \\
\text { oval }\end{array}$} & \multicolumn{2}{|c|}{$\begin{array}{c}\text { Strongly } \\
\text { Agree }\end{array}$} & \multicolumn{2}{|c|}{ Agree } & \multicolumn{2}{|c|}{ Neutral } & \multicolumn{2}{|c|}{ Disagree } & \multicolumn{2}{|c|}{$\begin{array}{l}\text { Strongly } \\
\text { Disagree }\end{array}$} & \multirow{2}{*}{ Phrases } & \multirow{2}{*}{$\mathbf{N}$} \\
\hline & & & $\%$ & ك5 & $\%$ & ك5 & $\%$ & ك5 & $\%$ & ك & $\%$ & ك5 & & \\
\hline **285.1 & 89.5 & 4.3 & 26.7 & 56.0 & 62.9 & 132.0 & 6.2 & 13.0 & 3.8 & 8.0 & 0.5 & 1.0 & $\begin{array}{l}\text { The social distancing associated with } \\
\text { COVID } 19 \text { negatively affects celebrations } \\
\text { of different sport events }\end{array}$ & 20 \\
\hline ** 188.0 & 68.6 & 22.4 & 13.3 & 28.0 & 55.2 & 116.0 & 9.0 & 19.0 & 21.9 & 46.0 & 0.5 & 1.0 & $\begin{array}{l}\text { The social distancing associated with } \\
\text { CovID } 19 \text { negatively affects administrative } \\
\text { work in the sports field(teams/clubs } \\
\text { /federations / Olympic committees / ...) }\end{array}$ & 21 \\
\hline **272.2 & 85.2 & 6.2 & 21.9 & 46.0 & 63.3 & 133.0 & 8.6 & 18.0 & 5.2 & 11.0 & 1.0 & 2.0 & $\begin{array}{l}\text { Some clauses of contracts between } \\
\text { professional players, clubs and various } \\
\text { sporting organizations will change } \\
\text { because of COVID } 19\end{array}$ & 22 \\
\hline ** 175.9 & 72.9 & 10.5 & 18.1 & 38.0 & 54.8 & 115.0 & 16.7 & 35.0 & 8.1 & 17.0 & 2.4 & 5.0 & $\begin{array}{l}\text { Some advertising contract items between } \\
\text { athletes and commercial institutions such } \\
\text { as (Coca-Cola - Vodafone - Adidas) will } \\
\text { be changed because of COVID } 19\end{array}$ & 23 \\
\hline **265.8 & 82.9 & 7.1 & 19.5 & 41.0 & 63.3 & 133.0 & 10.0 & 21.0 & 6.2 & 13.0 & 1.0 & 2.0 & $\begin{array}{l}\text { Insurance companies will change some } \\
\text { clauses of their future contracts with } \\
\text { players because of COVID } 19\end{array}$ & 24 \\
\hline **245.4 & 88.1 & 7.1 & 30.0 & 63.0 & 58.1 & 122.0 & 4.8 & 10.0 & 6.2 & 13.0 & 1.0 & 2.0 & $\begin{array}{l}\text { Because of COVID 19, the gains and } \\
\text { enjoyment of popular sports like soccer } \\
\text { will be reduced as they will be played } \\
\text { without fans. }\end{array}$ & 25 \\
\hline
\end{tabular}

chi square tabular at 0.01 level $=13.27 * *$ significant at 0.01 level 
Table (7) chi square test the health axis phrases $(n=210)$

\begin{tabular}{|c|c|c|c|c|c|c|c|c|c|c|c|c|c|c|}
\hline \multirow{2}{*}{$\begin{array}{c}\text { chi } \\
\text { square }\end{array}$} & \multirow{2}{*}{$\begin{array}{l}\text { Total } \\
\text { approv } \\
\text { al } \\
\text { percent } \\
\text { age }\end{array}$} & \multirow{2}{*}{$\begin{array}{l}\text { Total } \\
\text { percent } \\
\text { age of } \\
\text { disappr } \\
\text { oval }\end{array}$} & \multicolumn{2}{|c|}{$\begin{array}{c}\text { Strongly } \\
\text { Agree }\end{array}$} & \multicolumn{2}{|c|}{ Agree } & \multicolumn{2}{|c|}{ Neutral } & \multicolumn{2}{|c|}{ Disagree } & \multicolumn{2}{|c|}{$\begin{array}{l}\text { Strongly } \\
\text { Disagree }\end{array}$} & \multirow{2}{*}{ Phrases } & \multirow{2}{*}{$\mathbf{N}$} \\
\hline & & & $\%$ & كs & $\%$ & ك & $\%$ & ك & $\%$ & ك & $\%$ & ك & & \\
\hline **92.8 & 18.6 & 44.3 & 5.2 & 11.0 & 13.3 & 28.0 & 37.1 & 78.0 & 34.8 & 73.0 & 9.5 & 20.0 & $\begin{array}{l}\text { Some international sports bodies will } \\
\text { seek financial compensation from China, } \\
\text { as COVID } 19 \text { started in the city of } \\
\text { Wuhan, causing huge losses to them. }\end{array}$ & 26 \\
\hline **237.0 & 75.7 & 4.3 & 15.7 & 33.0 & 60.0 & 126.0 & 20.0 & 42.0 & 2.9 & 6.0 & 1.4 & 3.0 & $\begin{array}{l}\text { Smart cities will play an important role in } \\
\text { reducing the spread of COVID } 19 \text { among } \\
\text { athletes through digitalized systems with an } \\
\text { ID for every player. }\end{array}$ & 27 \\
\hline **249.1 & 91.9 & 1.9 & 38.6 & 81.0 & 53.3 & 112.0 & 6.2 & 13.0 & 1.4 & 3.0 & 0.5 & 1.0 & $\begin{array}{l}\text { In the presence of COVID 19, the } \\
\text { athlete's nutritional components will } \\
\text { change to include an increase in } \\
\text { immune-acquisition foods }\end{array}$ & 28 \\
\hline$* * 99.1$ & 66.2 & 16.2 & 22.9 & 48.0 & 43.3 & 91.0 & 17.6 & 37.0 & 15.2 & 32.0 & 1.0 & 2.0 & $\begin{array}{l}\text { In the presence of COVID 19, nutritional } \\
\text { supplements will be added or increased } \\
\text { in athletes' food }\end{array}$ & 29 \\
\hline$\star * 94.3$ & 69.5 & 11.4 & 31.9 & 67.0 & 37.6 & 79.0 & 19.0 & 40.0 & 10.0 & 21.0 & 1.4 & 3.0 & $\begin{array}{l}\text { The discovery of COVID } 19 \text { vaccination } \\
\text { and/or treatment will lead to a return to } \\
\text { sporting life just as it was before the } \\
\text { pandemic }\end{array}$ & 30 \\
\hline **261.8 & 94.3 & 1.4 & 43.3 & 91.0 & 51.0 & 107.0 & 4.3 & 9.0 & 1.0 & 2.0 & 0.5 & 1.0 & $\begin{array}{l}\text { Attention to preventive sports medicine will } \\
\text { increase due to COVID } 19\end{array}$ & 31 \\
\hline **288.5 & 95.7 & 1.0 & 39.0 & 82.0 & 56.7 & 119.0 & 3.3 & 7.0 & 0.5 & 1.0 & 0.5 & 1.0 & $\begin{array}{l}\text { Because of COVID 19, international } \\
\text { scientific cooperation will increase to find a } \\
\text { protocol to secure the safe return of the } \\
\text { international sport }\end{array}$ & 32 \\
\hline
\end{tabular}




\begin{tabular}{|l|l|l|l|l|l|l|l|l|l|l|l|l|l|}
\hline${ }^{* * 80.5}$ & 26.2 & 33.3 & 6.7 & 14.0 & 19.5 & 41.0 & 40.5 & 85.0 & 25.2 & 53.0 & $\mathbf{8 . 1}$ & $\mathbf{1 7 . 0}$ & $\begin{array}{l}\text { The World Military Championships in } \\
\text { October 2019 in Wuhan (China), with the } \\
\text { participation of 100 countries and 10,000 } \\
\text { athletes, was an important reason for the } \\
\text { COVID 19 outbreak worldwide. }\end{array}$ \\
\hline${ }^{* \star 205.2}$ & 64.3 & 14.3 & 7.1 & 15.0 & 57.1 & 120.0 & 21.4 & 45.0 & 13.3 & 28.0 & 1.0 & 2.0 & $\begin{array}{l}\text { Due to COVID 19, medical protocols will } \\
\text { reduce the personal freedom of } \\
\text { professionals in the sports field }\end{array}$ \\
\hline \hline
\end{tabular}

chi square tabular at 0.01 level $=13.27 * *$ significant at 0.01 level 
Tables No. $(4,5,6$, and 7$)$ show the chi-square test, where significant differences were found between the frequency of responses at the level of $(0.01)$, in the answer to no agreement or agreement in all axes :

\section{-General Sports Axis:}

- The level of athletic performance in team games will be negatively affected by Covid 19 with an approval rate $(83.3 \%)$, which is more than that achieved in digital .individuality (swimming - weightlifting - ...) and with approval $(67.7 \%)$ only - The respondents saw that Covid 19 does not have any positive effect on heroic sport by $(64.8 \%)$.

- It is believed that sports championships will return to normal after Covid 19 within 1 to 2 years $(92.8 \%)$.

- COVID 19 will lead to the development of sportswear and personal tools for players with approval (74.3\%), and the development of structural engineering for open and .(closed stadiums with approval (79.4\%).

- Affected by COVID 19, scientific programs in academic sports institutes must be modified with approval (79.5\%).

- The biggest obstacle to the return of major sports tournaments, such as the Olympiad, is the participation of a very large number of athletes from multiple countries, with approval of $(80.0 \%)$.

- Covid-19 will increase the role of information technology to protect athletes from infection by an approval rate $(90 \%)$.

\section{-The psychological axis}

-Fear of COVID 19 will cause a negative effect on the psyche of the players, and affect the effectiveness of sports training with close approval (89.5\%) and (88.6\%). We believe that various recreation inside the home is an important way out to mitigate the negative effects and anxiety referred to, and in this regard, Eman Abdulaziz points out (2020) referred to the appropriate activities for university youth while staying at home due to the COVID 19 pandemic and to the importance of designing recreational programs that suit their preferences during study breaks in emergency circumstances, (1:56 ).

\section{The economic axis}

The social distancing associated with COVID 19 negatively affects celebrations of various sporting events and administrative work in the sports field (teams/clubs /federations / ...) with two approval rates $(89.5 \%$ and $68.6 \%)$.

- Some contract clauses will change between professional players and clubs and various sports organizations, commercial advertising institutions, insurance companies; Due to COVID 19, with approval rates $(85.2 \%, 72.9 \%, 82.9 \%)$.

- The absence of spectators from stadiums, especially as densely populated as football, for fear of COVID 19, will lead to a reduction in financial gains and entertainment by an approval rate $(88.1 \%)$.

-It should be noted that the sports industry provides at its lowest estimates, up to 700 billion dollars annually, or $1 \%$ of the international gross product (4).

\section{The health axis :}

-Smart cities will play an important role in limiting the spread of COVID 19 among athletes through systems based on digitization, with a digital ID for every player in the (ID) sector of the tournament with approval $(75.7 \%)$. In this regard, Denis Loveridge (2009) indicates that Foresight led to the emergence of knowledge societies, 
sustainable development, and high-tech applications such as (biotechnology, artificial intelligence, nanotechnology, and others), (2:331).

- For resistance to COVID 19, the athlete's diet will include immune gain types and nutritional supplements with an approval rate $(91.9 \%$ and $66.2 \%)$.

- The discovery of vaccination and/or treatment for COVID 19 will lead to the return of sports life as it was before the pandemic, with an approval rate $(69.5 \%)$. - The interest in preventive sports medicine due to COVID 19 will increase, with an approval rate $(94.3 \%)$, and medical protocols will reduce the personal freedom of workers in the sports field with the approval of (64.3\%).

- Due to COVID 19, international scientific cooperation will increase to find a health protocol to ensure the safe return of international sport, with approval (95.7\%).

\section{Conclusions:}

- One to two years, the expected period for the return of the sports tournaments as they were before the occurrence of the outbreak.

- The very large numbers of athletes participating in major tournaments such as the Olympiad are the major obstacle to the return of these demonstrations to normal before the emergence of COVID 19.

- Amending programs in academic and sports institutions is a necessity imposed by the Covid-19 pandemic.

- There will be developments in the structural engineering of outdoor and indoor playgrounds to achieve health safety.

- The sportswear and personal equipment for the players will develop due to COVID 19

- The psychological component of the players will be negatively affected by fear of COVID 19 disease.

- Some terms of contracts between professional players, clubs, and sports bodies will change due to COVID 19.

- Insurance companies will change some of their futures contracts for players due to COVID 19.

- The components of the athlete's diet will change to include an increase in the types that raise immunity to prevent COVID 19.

\section{References:}

1- Iman Abdel Aziz Abdel Wahab (2020): A survey study of the recreational activities that university youth practice during the study break due to the emerging corona virus, Scientific Journal of Sports Science and Arts, College of Physical Education for Girls, Helwan University, Egypt, Volume 26, Issue 26, pg 56.

2- Denis Loveridge (2009): Foresight: The art and science of anticipating the future, Routledge - New York and London.

3 - https://www.who.int/ar -2019/

4 -https://www.mugtama.com . 


\section{Attachment (1)}

Thanks to all respondents to the study questionnaire (210 respondents), including:

-Vice President of Sinai University - Professor of Sports Psychology .

- Some deans of the Faculties of Physical Education in Egypt and Libya (current and former).

- Some vice deans of Faculties of Physical Education in Egypt.

- Professors at the Faculties of Physical Education.

- Winner of the silver medal in judo at the 1984 Los Angeles Olympic Games.

- Vice President of the Technical Committee of the International

Gymnastics Federation.

- Olympic male and female players in several sporting activities .

- Minister former head of the Sports Authority in 2016.

- President of Alexandria Sports Club (Sporting) in Egypt .

- Coach of the Egyptian women beach volleyball team at the Rio de Janeiro

Olympic Games.

- Coaches of national teams in several sporting activities .

- Members of some boards of directors of sports federations in Egypt.

- Sports journalists in the media in Egypt.

- Former head of the Olympic Military Center in Alexandria (Ph.D.).

- First Deputy Minister of Sports in Egypt, Chairman of the Board of Directors of the Central Sports Medicine Center. 